\title{
TEMPERATURE, LIGHT, AND DESICCATION TOLERANCE IN SEED GERMINATION OF Mauritia flexuosa L.F. ${ }^{1}$
}

Lívia Caroline Praseres de Almeida ${ }^{2}$,Kathia Fernandes Lopes Pivetta ${ }^{3}$, Renata Gimenes ${ }^{4}$,Gustavo de Nobrega Romani ${ }^{4}$, Marcos Vieira Ferraz $^{4 *}$ and Renata Bachin Mazzini-Guedes ${ }^{5}$

\footnotetext{
${ }^{1}$ Received on 05.02.2018 accepted for publication on 11.06.2018.

${ }^{2}$ Universidade Estadual Paulista, Mestrado em Agronomia, Jaboticabal, SP-Brasil. E-mail: <liviapraseres@ifma.edu.br>. ${ }^{3}$ Universidade Estadual Paulista, Departamento de Produção Vegetal, Jaboticabal, SP-Brasil. E-mail: <kathiaflpivetta@hotmail.com> ${ }^{4}$ Universidade Estadual Paulista, Doutorado em Agronomia, Jaboticabal, SP-Brasil. E-mail: $<$ renatagimenesfl@gmail.com>,<gnromani@gmail.com>and <ferrazmarcos@yahoo.com.br>.

${ }^{5}$ Universidade Federal do Paraná, Jandaia so Sul, Paraná,Brasil. E-mail: <remazzini@yahoo.com.br>

*Corresponding author.
}

\begin{abstract}
Palm trees are widely used as ornamental plants, besides its sustainability and industry aspects. These plants are commercially propagated via seeds. Due to its importance and the need for seed germination information, this study aimed to verify the effect of temperature, light regimes, and desiccation tolerance on germination of Mauritia flexuosa L.f. For that, two completely randomized experiments were carried out. The first consisted of treatments arranged in a $6 \times 2$ factorial scheme, testing six temperatures $(20,25,30$, $35,20-30$, and $25-35^{\circ} \mathrm{C}$ ) and light presence and absence. The second comprised five seed water contents $(51,48,45,30$, and $26 \%)$ for desiccation tolerance evaluations. Water content measurements were made every three days, from a sample lot maintained at room temperature. In both trials, each treatment was composed of four replicates with 25 seeds per plot. Germination rate (GR) and germination speed index (GSI) were calculated, and the data were analyzed by analysis of variance (ANOVA). Temperature and light means were compared by the Tukey's test $(p \leq 0.05)$, and the desiccation ones by a polynomial regression. The highest GR was observed at $20-30^{\circ} \mathrm{C}$, regardless of light presence. Moreover, $M$. flexuosa seeds were sensitive to desiccation.
\end{abstract}

Keywords: Arecaceae; Buriti; Palm tree.

\section{TEMPERATURA, LUZ E TOLERÂNCIA À DESSECAÇÃO NA GERMINAÇÃO DE SEMENTES DE Mauritia flexuosa L.F.}

\begin{abstract}
RESUMO - As palmeiras são amplamente utilizadas como plantas ornamentais, além da importância para a sustentabilidade e para a indústria. A propagação comercial destas plantas é realizada por meio de sementes. Devido à importância da espécie e à necessidade de elucidar alguns aspectos relacionados à germinação das sementes, este trabalho teve como objetivo verificar o efeito de temperatura, regimes de luz e tolerância a dessecação na germinação de sementes da palmeira Mauritia flexuosa L.f. Foram realizados dois experimentos e em ambos o delineamento experimental foi o inteiramente casualizado. No primeiro, estudou-se o efeito da temperatura e da luz e os tratamentos foram dispostos em esquema fatorial $6 x 2$ (seis temperaturas: $20{ }^{\circ} \mathrm{C}, 25{ }^{\circ} \mathrm{C}, 30^{\circ} \mathrm{C}, 35{ }^{\circ} \mathrm{C}, 20-30^{\circ} \mathrm{C}$ e $25-35^{\circ} \mathrm{C}$ combinadas com presença e ausência de luz); foram quatro repetições de 25 sementes por parcela. No segundo, estudou-se a tolerância a dessecação e os tratamentos foram cinco teores de água nas sementes $(51 \%, 48 \%, 45 \%, 30 \%$ e 26\%) aferidos a cada três dias de um lote mantido em condições ambiente; foram quatro repetições de 25 sementes por parcela. Avaliou-se a porcentagem de germinação e Índice de Velocidade de Germinação. Os dados foram submetidos à análise de variância; as médias de temperatura e de luz foram comparadas pelo teste de Tukey $(P \leq 0.05)$ e para dessecação realizou-se a análise de regressão polinomial. A temperatura de $20-30{ }^{\circ} \mathrm{C}$ foi a que apresentou maiores médias de porcentagem e de velocidade de germinação independentemente da presença ou ausência de luz. As sementes de M. flexuosa se mostraram sensiveis à dessecação.
\end{abstract}

Palavras-Chave: Arecaceae; Buriti; Palmeira. 


\section{INTRODUCTION}

Mauritia flexuosa L.f. is a palm species of the family Arecaceae, commonly known as moriche palm or buriti. It has solitary, column-like stems and palmate leaves, and is able to reach $25 \mathrm{~m}$ in height and 0.80 $\mathrm{m}$ in diameter. This species occurs in the flooded and wet regions of several Brazilian states (Lorenzi et al., 2010). Although native to Brazil, M. flexuosa is not endemic, and can be found in diverse ecosystems. This species can be encountered in Amazonia, Caatinga, and Cerrado biomes, as well as in riparian/gallery forests, floodplains, and palm savannas in the states of Acre, Amazonas, Pará, Rondônia, Tocantins, Bahia, Ceará, Maranhão, Piauí, Federal District, Goiás, Mato Grosso do Sul, Mato Grosso, Minas Gerais, and São Paulo (Arecaceae..., 2018).

Besides being widely cultivated in Brazil, this species has great socioeconomic importance. The fruit, which is commonly traded, is a good source of vitamins and minerals, besides contributing to fauna preservation since it serves as food for wild animals (Milanez et al., 2018).

In addition, this palm species has a great ornamental value, as do the majority of palm trees. The leaves are used as a roof material for thatched houses; the fruits serve as food for people in juices and candies; the petioles are used to make toys and handicrafts (Lorenzi et al., 2010).

This palm is commercially propagated via seed. If compared to many other species, it has a low germination rate, which is slow and uneven due to several factors (Pivetta et al., 2007).

Germination can be influenced directly or indirectly by temperature, which impairs seed viability, dormancy overcoming, deterioration time, water absorption speed, and biochemical reactions during germination (Marcos Filho, 2015; Mahmood et al., 2016). Among other aspects, this climatic factor can reduce germination total rate, speed, and uniformity (Carvalho and Nakagawa, 2000; Castro and Hilhorst, 2004).

In general, palm seeds require high temperatures to achieve maximum germination rate, speed, and uniformity. The temperature range between 21 and 38 ${ }^{\circ} \mathrm{C}$ is suitable, but the best results are reached between 29 and $35^{\circ} \mathrm{C}$ (Meerow and Broschat, 2015).

Although most species of palm trees are of tropical origin, of which seeds are naturally germinated at high temperatures, some studies have shown interference of this factor variation on germination rates and speed, depending on the species. Pivetta et al. (2013) verified higher rates and speed levels in seeds of Roystonea regia (H. B. K.) O. F. Cook at a constant temperature of $35^{\circ} \mathrm{C}$. Likewise, Luz et al. (2017) observed higher values for seeds of Archontophoenix cunninghamii H. Wendl. \& Drude at a constant temperature of 25 ${ }^{\circ} \mathrm{C}$ and alternating of $25-35^{\circ} \mathrm{C}$. For Costa et al. (2018), a temperature of $20^{\circ} \mathrm{C}$ provides higher germination rates and speed for Euterpe precatoria Mart.

Another factor that can interfere with seed germination would be light (Castro and Hilhorst, 2004). Seeds of Livistona chinensis (N. J. Jacquin) R. Brown ex Mart. present a high germination rate regardless of the light regime; however, the process is faster in the presence of light (Kobori et al., 2009). Conversely, this factor was found to be unresponsive in Euterpe edulis Mart. (Aguiar et al., 2017) and E. precatoria (Costa et al., 2018).

Seeds of many species lose viability after dehydration (Tweddle et al., 2003), what varies widely among species (Berjak and Pammenter, 2008). The majority of palm species are considered recalcitrant, that is, they lose viability when water contents reach values lower than those considered critical and, if it is equal to or below those considered lethal, viability is totally lost (Martins et al., 1999).

Given the importance of this species, this study aimed to verify the effect of different temperatures, light presence, and desiccation tolerance on germination of buriti seeds (M. flexuosa), so that germination-related aspects could be elucidated for further production of high-quality seedlings at a large scale.

\section{MATERIALAND METHODS}

Fruits of Mauritia flexuosa were harvested from 10 palms planted at a farm in Buritizal city, São Paulo state (SP), Brazil. The collections were held on November 7 (2016) and February 20 (2017), using a pruning knife. Criteria for harvest was based upon fruit color (reddishbrown) and only the fallen fruits were taken, as an indicator of maturity. After harvesting, the fruits were packed in plastic bags and transported to the Laboratory of Vegetable Seed Analysis, State University of São Paulo (UNESP) - Jaboticabal Campus - SP.

In the laboratory, two experiments were carried out. The first was conducted between November 2016

Revista Árvore. 2018;42(3):e420305 
and March 2017 to test the effects of temperature and light on buriti seed germination. Whereas the second was carried out between February 2017 and July 2017 to evaluate the effect of desiccation levels on seed germination.

\subsection{Temperature and light effects}

The experimental design was completely randomized, and treatments were arranged in a $6 \times 2$ factorial scheme with four replicates of 25 seeds. The treatments consisted of six temperature conditions $\left(20^{\circ} \mathrm{C}, 25^{\circ} \mathrm{C}, 30^{\circ} \mathrm{C}, 35\right.$ ${ }^{\circ} \mathrm{C}, 20-30{ }^{\circ} \mathrm{C}$, and $25-35^{\circ} \mathrm{C}$ ) and light absence and presence. In this experiment, seed water content was about $48 \%$.

Soon after arrival in the laboratory, the fruits were immersed in water for 24 hours. Then, fruit pulp (epicarp and mesocarp) was removed by friction against a steel mesh screen. After pulping, two samples of 10 pyrenes (seed plus endocarp) were used for water content gravimetrical determination, after drying in an oven for 24 hours at $105 \pm 3{ }^{\circ} \mathrm{C}$ (Brasil, 2009).

For light treatment, samples were placed into clear plastic boxes $(20 \times 12 \times 6 \mathrm{~cm})$, which were stored in polyethylene bags, transparent for the light presence and black for absence, and left under artificial lightning. The boxes were filled with medium vermiculite as a substrate, which was maintained at $100 \%$ water retention capacity. These boxes were then placed in germination chambers, with the temperature set according to treatment. Photoperiod length was of $12 \mathrm{~h}$.

\subsection{Desiccation tolerance}

The experimental design was completely randomized with five treatments, which consisted of seed water contents $(51 \%, 48 \%, 45 \%, 30 \%$, and $26 \%)$.

After arrival in the laboratory, the fruits were pulped. The initial water content of seeds was $51 \%$ and corresponded to the first treatment. Then, pyrenes were placed on a bench under environmental conditions for a gradual loss of seed water. Every three days, moisture measurements were taken, and fruits were placed into clear plastic boxes $(20 \times 12 \times 6 \mathrm{~cm})$ with medium vermiculite as substrate (maintained at $100 \%$ water capacity), which were packed in plastic bags or germination in a chamber at $20-30{ }^{\circ} \mathrm{C}$. These measures were taken within 12 days, comprising the other four treatments $(48 \%, 45 \%$, $30 \%$, and $26 \%$ ). Each plot consisted of four replicates with 25 seeds. For each treatment, water content measurements were made in two samples of 10 pyrenes, as recommended in Brasil (2009).

\subsection{Statistics}

Seeds were considered germinated upon germinative bud appearance. Germinated seeds were counted daily at the same time, until germination stabilization in all treatments. For temperature and light experiment, it lasted 120 days, and for desiccation experiment, 150 days.

Germination Speed Index (GSI) was calculated using the formula proposed by Maguire (1962). For statistical analysis, germination percentage data were transformed to $\operatorname{arcsine}(\mathrm{x} / 100)^{1 / 2}$.

Data underwent analysis of variance (ANOVA). Means of the first experiment were compared by the Tukey's test ( $p$ d" 0.05), and those of the second by polynomial regression; this analysis was used to verify the behavior of variables as a function of water content reductions. The best fit was defined by combining significance and higher determination coefficients.

\section{RESULTS}

No significant interaction between temperature and light was observed for germination rate(GR) and GSI. However, both variables showed significant differences among temperatures. The light presence had no significant results for both variables (Table 1).

A negative linear fit was found between GR and GSI in the second study, and values decreased with seed water content reductions (Figure 1).

The highest GR (91\%) was observed at the time of harvest when seeds had a water content of $51 \%$. After desiccation, this rate decreased $(81 \%, 72 \%, 64 \%$ and $47 \%)$ with moisture loss $(48 \%, 45 \%, 30 \%$, and $26 \%$, respectively).

Again, the highest GSI was at harvest (1.2490) and, as seeds were dried, it reduced ( 1.0993 at $48 \%, 0.8973$ at $45 \%, 0.7358$ at $30 \%$, and 0.6250 at $26 \%$ ).

\section{DISCUSSION}

In this study, we found that alternating temperatures provided the highest GR $\left(20-30^{\circ} \mathrm{C}\right)$ and GSI $\left(20-30{ }^{\circ} \mathrm{C}\right)$ for $M$. flexuosa seeds (with or without light). The same has been reported for other palm species such as Bactris

Revista Árvore. 2018;42(3):e420305 
Table 1 - Mean squared errors and averages for germination rate (GR) and germination speed index (GSI) of Mauritia flexuosa L f. seeds under different temperature and light conditions.

Tabela 1 - Quadrados médios e médias obtidas nas análises de variância para porcentagem de germinação $e$ Índice de Velocidade de Germinação (IVG), de sementes de Mauritia flexuosa $L f$., em diferentes condições de temperatura e luz.

\begin{tabular}{lccc}
\hline Variation sources & DF & GR $(\%)$ & GSI \\
\hline Temperature (T) & 5 & $3376.6^{* *}$ & $0.5009^{* *}$ \\
Light (L) & 1 & $3.0^{\mathrm{NS}}$ & $0.0016^{\mathrm{NS}}$ \\
$\mathrm{T} \mathrm{x} \mathrm{L}$ & 5 & $35.0^{\mathrm{NS}}$ & $0.0034^{\mathrm{NS}}$ \\
Residue & 32.3 & 0.0137 \\
\hline $\mathrm{CV}(\%)$ & 10.39 & 12.63 \\
\hline Means & & \\
Temperature & & \\
$20^{\circ} \mathrm{C}$ & $28.5 \mathrm{~d}^{1}$ & $0.7813 \mathrm{~b}$ \\
$25^{\circ} \mathrm{C}$ & $45.5 \mathrm{c}$ & $0.7850 \mathrm{~b}$ \\
$30^{\circ} \mathrm{C}$ & $49.0 \mathrm{c}$ & $0.7475 \mathrm{~b}$ \\
$35^{\circ} \mathrm{C}$ & $48.0 \mathrm{c}$ & $0.7450 \mathrm{~b}$ \\
$20-300^{\circ} \mathrm{C}$ & $86.0 \mathrm{a}$ & $1.2400 \mathrm{a}$ \\
$25-35^{\circ} \mathrm{C}$ & & $71.5 \mathrm{~b}$ & $1.2563 \mathrm{a}$ \\
Light & & & \\
Presence & & $54.5 \mathrm{a}$ & $0.9200 \mathrm{a}$ \\
Absence & & $55.0 \mathrm{a}$ & $0.9317 \mathrm{a}$ \\
\hline 1/ original (not transformed) values & &
\end{tabular}

NS - non-significant $(p>0.05) ; * *$ significant at $1 \%$ probability level $(p<0.01)$

Means followed by the same letter in the column do not differ from each other by the Tukey's test at $5 \%$ probability.

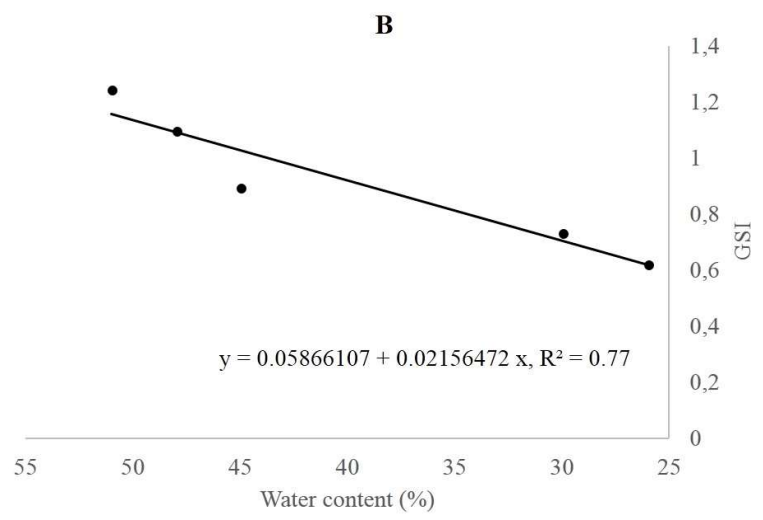

Figure 1 - Regression curves between (A) germination rate (data transformed to arcsine $\left.(\mathrm{x} / 100)^{1 / 2}\right)$ and (B) germination speed index (GSI) for different water contents in buriti seeds (Mauritia flexuosa $\mathrm{L} \mathrm{f}$.).

Figura 1 - Curvas de regressão entre (A) Porcentagem de germinação (dados transformados em arc seno $\left.(x / 100)^{1 / 2}\right)$ e (B) Índice de Velocidade de Germinação (IVG) e diferentes teores de água em sementes de buriti (Mauritia flexuosa $L f$.). maraja Mart. (Rodrigues et al., 2014) and Phoenix canariensis Hort. ex Chabaud (Pimenta et al., 2010).

The GR values observed here were higher than the rates found for other palm species of genus Euterpe such as E. edulis and E. oleracea Mart. (BeckmannCavalcante et al., 2012) and E. oleracea (Pivetta and Luz, 2013). Likewise, Meerow and Broschat (2015) observed that alternating temperatures at 12-hour intervals promoted increases in overall GR for some palm species.

Alternating-temperature responsive seeds have enzymatic mechanisms able to function at different temperatures (Vázquez-Yanes and Orozco-Segovia, 1987). According to Borges and Rena (1993), this response might be an adaptation to natural environmental variations. On the other side, Costa et al. (2018) reported that a constant temperature of $20^{\circ} \mathrm{C}$ provided the highest GR and GSI means for E. precatoria, both in light and darkness. Therefore, the ideal temperature should be determined for each species since it interferes with seed germination rate, speed, and uniformity (Castro and Hilhorst, 2004).

We also observed that light was not an essential factor for M. flexuosa germination. As a result, these seeds could be considered as neutral photoblastic, as already suggested by other authors (Vázquez-Yanes and Orozco-Segovia, 1990; Marcos Filho, 2015). This light indifference is a behavior usually observed in the germination of sub-forest species and shade plants (Andrade, 1995). For instance, we may cite other palm species such as Aiphanes aculeata Willd. (Silva et al., 1999), Rhapis excelsa (Thunberg) Henry ex. Rehder (Aguiar et al., 2005), Livistona chinensis (Kobori et al., 2009) and E. precatoria (Costa et al., 2018).

Desiccation tolerance is a clearly advantageous potential that allows seed survival over time and in arid environments (Pammenter and Berjak, 2000). This trait is measured by the critical water content for each species, below which germination ceases (Hill et al., 2010). Félix et al. (2017) claimed that such content might vary considerably from one palm species to another, especially when they are from different climatic regions. Such a variation has already been verified for Oenocarpus bacaba Mart. seeds, which do not stand drying below $27 \%$ humidity, therefore being classified as recalcitrant (José et al., 2012). Another case is Corypha umbraculifera L. seeds, which maintain GR above $53 \%$ even after being dehydrated to $17 \%$ moisture level, a characteristic

Revista Árvore. 2018;42(3):e420305 
of intermediate seeds (Viji et al., 2013). We can also cite the orthodox seeds, as the case of Orbignya phalerata Mart., which are able to maintain GRs above $55 \%$ until a 5\% moisture content (Silva et al., 2012).

Batista et al. (2016) found that seeds of Dypsis decaryi (Jum.) Beentje \& J. Dransf. and Ptychosperma elegans (R. $\mathrm{Br}$.) Blume had germination reduced as seed water contents decreased to $20 \%$ and $27 \%$, respectively, showing to be sensitive to desiccation. In contrast, the same authors classified the seeds of Carpentaria acuminata (H. Wendl. \& Drude) Becc. and P. canariensis as desiccation tolerant since they presented GRs of $70 \%$ and $76 \%$ as moisture contents decreased by $8 \%$ and $5 \%$, respectively. Similarly, Costa et al. (2018) observed that the GRs of E. precatoria seeds at $11 \%$ moisture level were above $69 \%$, therefore being also considered as tolerant.

At harvest, when seed water content was $51 \%$, GR was $91 \%$ observed by Bastos (2014) for O. bacaba palm seeds that showed high germination ( $80 \%$ ) when newly harvested and with $41.1 \%$ water content. This rate fell from 91 to $47 \%$ when the water content of seeds decreased (51 to $26 \%$ ) within the 12 days of evaluation. Although it is a sharp fall, this rate is still not considered critical, as is $26 \%$. However, we can consider these seeds desiccation sensitive as in the case of D. decaryi and P. elegans (Batista et al., 2016).

Rodrigues et al. (2014) observed that the seedling emergence of $B$. maraja palms decreased $37 \%$ when seed water contents went from $23.6 \%$ to $7.8 \%$, but the seeds can still be regarded as tolerant. Félix et al. (2017) verified that the seedling emergence of Adonidia merrillii (Becc.) Becc. was $100 \%$ at $44 \%$ humidity and remained above $92 \%$ until $28 \%$ but fell rapidly until become unviable at $16 \%$ (recalcitrant).

Although recalcitrant seeds have elevated GRs under conditions of high moisture, water contents above $25 \%$ at temperatures above $20^{\circ} \mathrm{C}$ favor the growth of fungi, what may be worsened by the release of reserve substances during seed deterioration. Therefore, seed desiccation at low temperatures could avoid such problems by not harming the embryo (Marcos Filho, 2015).

\section{CONCLUSION}

The alternating temperature of $20-30{ }^{\circ} \mathrm{C}$ resulted in the highest values of germination rate and speed for M. flexuosa seeds, regardless of light presence. These seeds are also sensitive to desiccation.

\section{ACKNOWLEDGMENTS}

The authors thank the National Council for Scientific and Technological Development (CNPq) for the financial support (Process $\mathrm{n}^{\circ}$ 484299/2013-1) and research productivity grant to the second author (Process $\mathrm{n}^{\circ}$ 308086/2012-0).

\section{REFERENCES}

Aguiar FFAA, Bilia DAC, Kanashiro S, Tavares AR, Barbedo CJ. Germinação de sementes de Rhapis excelsa (Thunb.) Henry ex Rehder: efeitos da temperatura, luz e substrato. Hoehnea. 2005;32:119-26.

Aguiar FFAA, Kanashiro S, Giampaoli P, Modolo VA, Aguiar J, Tavares AR. Effects of light, temperature and mesocarp on seed germination of Euterpe edulis (juçara-palm). Bioscience Journal. 2017;33:881-5.

Andrade ACS. Efeito da luz e da temperatura na germinação de Leandra breviflora Cogn., Tibouchina benthamiana Cogn., Tibouchina grandifolia Cogn. e Tibouchina moricandiana (Dc.) Baill. (Melastomaceae). Revista Brasileira de Sementes. 1995; 17:29-35.

Arecaceae in Flora do Brasil 2020 em construção. Jardim Botânico do Rio de Janeiro. [acessado em: 07 Jun. 2018] Disponível em: http:// floradobrasil.jbrj.gov.br/reflora/floradobrasil/FB15723.

Bastos LLS. Germinação de sementes de Oenocarpus Mart.: efeito do dessecamento em sementes de Oenocarpus bacaba Mart. e da temperatura em sementes de Oenocarpus bataua Mart. [dissertação]. Manaus: Instituto Nacional de Pesquisas da Amazônia - INPA; 2014.

Batista GS, Mazzini-Guedes RB, Pivetta KFL, Pritchard HW, Marks T. Seed desiccation and salinity tolerance of palm species Carpentaria acuminata, Dypsis decaryi, Phoenix canariensis, and Ptychosperma elegans. Australian Journal of Crop Science. 2016;10:1630-4.

Beckmann-Cavalcante MZ, Pivetta, KFL, Ilha LL, Takane, RJ. Temperatura, escarificação mecânica e substrato na germinação de sementes das palmeiras juçara e açaí. Revista Brasileira de Ciências Agrárias. 2012;7:569-73. 
Berjak P, Pammenter NW From Avicennia to Zizania: seed recalcitrance in perspective. Annals of Botany. 2008;101:213-28.

Borges EEL, Rena AB. Germinação de sementes. In: Aguiar IB, Pinã-Rodrigues FCM, Figliolia MB. Sementes florestais tropicais. Brasília, DF: ABRATES; 1993.

Brasil. Ministério da Agricultura, Pecuária e Abastecimento. Regras para análise de sementes. Brasília: Secretaria de Defesa Agropecuária; 2009.

Carvalho MM, Nakagawa J. Sementes: ciência, tecnologia e produção. $4^{\mathrm{a}}$.ed. Jaboticabal: Funep; 2000.

Castro RD, Hilhorst HWM. Embebição e reativação do metabolismo. In: Ferreira AG, Borghetti F, editors. Germinação: do básico ao aplicado. Porto Alegre: Artmed; 2004.

Costa CRX, Pivetta KFL, Souza GBR, MazziniGuedes RB, Pereira STS, Nogueira MR. Effects of temperature, light and desiccation on seed germination of Euterpe precatoria palm. American Journal of Plant Sciences. 2018;9:98-106.

Félix FC, Araújo FS, Ferrari CS, Pacheco MV. Dessecação e armazenamento de sementes de Adonidia merrillii (Becc.) Becc. Agrária. 2017;12:86-91.

Hill JP, Edwards W, Franks PJ, How long does it take for different seeds to dry. Functional Plant Biology. 2010;37:575-83.

José AC, Erasmo EAL, Coutinho AB. Germinação e tolerância à dessecação de sementes de bacaba (Oenocarpus bacaba Mart.). Revista Brasileira de Sementes. 2012;34(4):651-7.

Kobori NN, Pivetta KFL, Demattê MESP, Silva BMS, Luz PB, Pimenta RS. Ffeito da temperatura e do regime de luz na germinação de sementes de Palmeiraleque-da-China (Livistona chinensis (Jack.) R. Br. ex. Mart.). Revista Brasileira de Horticulta Ornamental. 2009;15:29-36.

Lorenzi H, Noblick L, Kahn F, Ferreira EJL. Flora Brasileira: Arecaceae (Palmeiras). Nova Odessa: Plantarum; 2010.

Luz PB, Tavares AR, Pivetta KFL. Germination of

Revista Árvore. 2018;42(3):e420305
Archontophoenix cunninghamiana (Australian king palm) seeds based on different temperatures and substrates. Ornamental Horticulture. 2017;23:166-71.

Maguire JD. Speed of germination in selection and evaluation of seedling emergence and vigor. Crop Science. 1962;2:176-7.

Mahmood AH, Florentine SK, Chauhan BS, Mclaren DA, Palmer GC, Wright W. Influence of various environmental factors on seed germination and seedling emergence of a noxious environmental weed: green galenia (Galenia pubescens). Weed Science. 2016;64:486-94.

Marcos Filho J. Fisiologia de sementes de plantas cultivadas. Piracicaba: FEALQ; 2015.

Martins CC, Nakagawa J, Bovi MLA. Tolerância à dessecação de sementes de palmito-vermelho (Euterpe espiritosantensis Fernandes). Revista Brasileira de Botânica. 1999;22:391-6.

Meerow AW, Broschat TK. Palm seed germination. Gainesville: UF/IFAS Extension, 2015.

(Environmental Horticulture Department, UF/IFAS Extension, BUL274).

Milanez JT, Neves LC, Colombo RC, Shahab M, Roberto SR. Bioactive compounds and antioxidant activity of buriti fruits, during the postharvest, harvested at different ripening stages. Scientia Horticulturae, 2018;227:10-21.

Pammenter NW, Berjak P. Evolutionary and ecological aspects of recalcitrant seed biology. Seed Science Research. 2000;10:301-6.

Pimenta RS, Luz PB, Pivetta KFL Castro A, Pizetta PUC. Efeito da maturação e temperatura na germinação de sementes de Phoenix canariensis hort. ex Chabaud - Arecaceae. Revista Árvore. 2010;34:31-8.

Pivetta KFL, Penariol AP, Pedrinho DR, Pimenta RS, Batista GS, Romani GN, et al. Effects of the Temperature and Maturation Stages on the Germination of Roystonea regia Seeds. Acta Horticulturae. 2013;1003:209-14.

Pivetta KFL, Luz PB. Efeito da temperatura e escarificação na germinação de sementes de 
Euterpe oleracea (Mart.) (Arecaceae). Revista de Biologia e Ciências da Terra. 2013;13:83-8.

Pivetta KFL, Barbosa JG, Araújo EF, Demattê MESP. Propagação de palmeiras e estrelitzia. In: Barbosa JG, Lopes LC. Propagação de plantas ornamentais. Viçosa, MG: UFV; 2007.

Rodrigues JK, Mendonça MS, Gentil DFO. Efeito da temperatura, extração e embebição de sementes na germinação de Bactris maraja Mart.

(Arecaceae). Revista Árvore. 2014;38(5):857-65.

Silva MAS, Castellani ED, Demattê MESP. Effect of fruit maturation stage and light on seed germination of Aiphanes aculeate. Acta Horticulturae. 1999;486(486):229-34.

Silva MVV, Sales JF, Silva FG, Rubino Neto A, Alberto PS, Pereira FD. The influence of moisture on the in vitro embryo germination and morphogenesis f babassu (Orbgnya phalerata).
Acta Scientiarum Agronomy. 2012;34(4):453-8.

Tweddle JC, Dickie JB, Baskin CC, Baskin JM. Ecological aspects of seed desiccation sensitivity. Journal of Ecology. 2003;91(2):294-304.

Vázquez-Yanes C, Orozco-Segovia A. Ecological significance of light controlled seed germination in two contrasting tropical habitats. Oecologia. 1990;83:171-5.

Vázquez-Yanes C, Orozco-Segovia A. Fisiología ecológica de semillas en la Estación de Biologia Tropical “Los Tuxtlas”, Veracruz, México. Revista de Biologia Tropical. 1987;35:85-96.

Viji V, Ratheesh CP, Nabeesa S, Puthur JT. Influence of desiccation and associated metabolic changes during seed germination in Corypha umbraculifera Linn. Journal of Stress Physiology \& Biochemisty. 2013;9(93):37-43. 